\title{
HBK-14 and HBK-15 with antidepressant-like and/or memory-enhancing properties increase serotonin levels in the hippocampus after chronic treatment in mice
}

\author{
Karolina Pytka ${ }^{1}$ (D) Katarzyna Gawlik ${ }^{2}$ - Dorota Pawlica-Gosiewska ${ }^{2}$. \\ Jadwiga Witalis $^{1} \cdot$ Anna Waszkielewicz ${ }^{3}$
}

Received: 3 August 2016 / Accepted: 14 November 2016/Published online: 25 November 2016

(C) The Author(s) 2016. This article is published with open access at Springerlink.com

\begin{abstract}
HT}_{1 \mathrm{~A}}$ and $5-\mathrm{HT}_{7}$ receptor ligands might have antidepressant-like properties and improve cognitive function. We previously reported significant antidepressant- and anxiolytic-like effects of two dual 5- $\mathrm{HT}_{1 \mathrm{~A}}$ and $5-\mathrm{HT}_{7}$ receptor antagonists in various behavioral tests in rodents. As a continuation of our previous experiments, in this study we aimed to investigate whether chronic administration of 1-[(2,6-dimethylphenoxy)ethoxyethyl]-4-(2methoxyphenyl)piperazine hydrochloride (HBK-14) and 1 -[(2-chloro-6-methylphenoxy)ethoxyethyl]-4-(2methoxyphenyl)piperazine hydrochloride (HBK-15) caused antidepressant-like effects and elevated serotonin levels in the murine hippocampus. We also evaluated cholinolytic properties and the influence of acute administration of both compounds on cognitive function in mice. To assess antidepressant-like properties and the influence on learning and memory we used forced swim test and stepthrough passive avoidance task in mice, respectively. Both compounds showed antidepressant-like properties and significantly elevated serotonin levels in the hippocampus after chronic treatment (HBK-14 - $2.5 \mathrm{mg} / \mathrm{kg}$; HBK-15 - 0.625 and $1.25 \mathrm{mg} / \mathrm{kg}$ ). HBK-15 administered chronically
\end{abstract}

Karolina Pytka

karolina.pytka@uj.edu.pl

1 Department of Pharmacodynamics, Faculty of Pharmacy, Jagiellonian University Medical College, Medyczna 9, 30-688 Krakow, Poland

2 Department of Diagnostics, Chair of Clinical Biochemistry, Jagiellonian University Medical College, Krakow, Poland

3 Department of Bioorganic Chemistry, Chair of Organic Chemistry, Faculty of Pharmacy, Jagiellonian University Medical College, Medyczna 9, 30-688 Krakow, Poland antidepressant-like activity at lower dose $(0.625 \mathrm{mg} / \mathrm{kg})$ than the dose active after acute treatment $(1.25 \mathrm{mg} / \mathrm{kg})$. None of the compounds affected locomotor activity of mice. HBK-15 possessed very weak cholinolytic properties, whereas HBK-14 did not show any effect on muscarinic receptors. Only HBK-15 $(0.625 \mathrm{mg} / \mathrm{kg})$ presented memory-enhancing properties and ameliorated cognitive impairments caused by scopolamine $(1 \mathrm{mg} / \mathrm{kg})$. Our results indicate that $5-\mathrm{HT}_{1 \mathrm{~A}}$ and $5-\mathrm{HT}_{7}$ antagonists might have potential in the treatment of depression and possess positive influence on cognitive function.

Keywords 2-methoxyphenylpiperazine derivative $\cdot 5-\mathrm{HT}_{1 \mathrm{~A}}$ receptor antagonist $\cdot 5-\mathrm{HT}_{7}$ receptor antagonist $\cdot$ Forced swim test $\cdot$ Step-through passive-avoidance test $\cdot$ Mice

\section{Introduction}

Major depression affects millions of people worldwide and contributes to their disability. Besides the well-defined depressive symptoms, patients often report cognitive disturbances, which significantly deteriorate their functioning. Therefore, the scientists still search for the new compounds with increased efficacy and positive influence on cognition.

Current antidepressants worsen (e.g. tricyclic antidepressants) or have no influence (e.g. selective serotonin reuptake inhibitors) on cognitive function (for review see: Biringer et al. 2009). Some Authors suggested that reboxetine, bupropion, duloxetine or venlafaxine might have more beneficial effect on cognitive function than other antidepressants. However, recent meta-analysis of clinical trials showed that only vortioxetine significantly improved cognition in depressed patients (McIntyre et al. 2016). Positive influence on cognitive function was most likely due to the drug's broad receptor profile. Studies on animals showed that both $5-\mathrm{HT}_{1 \mathrm{~A}}$ and 5- 
$\mathrm{HT}_{7}$ receptor ligands might enhance cognitive function in rodents (reviewed in Glikmann-Johnston et al. 2015 and Meneses 2014). Interestingly, 5- $\mathrm{HT}_{1 \mathrm{~A}}$ antagonism facilitated memory retention possibly via $5-\mathrm{HT}_{7}$ activation, and $5-\mathrm{HT}_{7}$ receptor could improve emotional memory upon reduced 5$\mathrm{HT}_{1 \mathrm{~A}}$ receptor transmission (Stiedl et al. 2015).

We previously reported significant antidepressant- and anxiolytic-like effects of two dual 5- $\mathrm{HT}_{1 \mathrm{~A}}$ and $5-\mathrm{HT}_{7}$ receptor antagonists in various behavioral tests in rodents (Waszkielewicz et al. 2015; Pytka et al. 2015a). As a continuation of our previous experiments, in this study we aimed to investigate whether chronic administration of 1-[(2,6dimethylphenoxy)ethoxyethyl]-4-(2-methoxyphenyl) piperazine hydrochloride (HBK-14) and 1-[(2-chloro-6methylphenoxy)ethoxyethyl]-4-(2-methoxyphenyl)piperazine hydrochloride (HBK-15) caused antidepressant-like effects and elevated serotonin levels in the murine hippocampus. We also evaluated cholinolytic properties and the influence of acute administration of both compounds on cognitive function in mice.

\section{Materials and methods}

\section{Animals}

Adult male mice (stock's name: CD-1, 18-21 g), purchased from Animal House at the Faculty of Pharmacy, Jagiellonian University Medical College, Krakow, Poland or and male guinea-pigs (Outbred CV, 300-400 g), purchased from Laboratory Animals Husbandry Maria Staniszewska, Słaboszów, Poland were used in the experiments. The groups of 15 mice or 2 guinea-pigs were kept to a plastic cage $(60 \mathrm{~cm} \times 38 \mathrm{~cm} \times 20 \mathrm{~cm})$ at a room temperature $\left(22 \pm 2{ }^{\circ} \mathrm{C}\right)$, on $12 \mathrm{~h} \mathrm{light/dark} \mathrm{cycles} \mathrm{(the} \mathrm{lights} \mathrm{turned} \mathrm{on} \mathrm{at}$ 7:00 a.m., and off at 19:00 p.m.). Animals had free access to standard laboratory food and tap water. Behavioral experiments were performed between 9 a.m. and 2 p.m. and each experimental group consisted of 8-10 randomly selected animals. In acute experiments mice were used only once in each test. After the experiment mice were killed by cervical dislocation. Guinea-pigs were anaesthetized $(37 \mathrm{mg} / \mathrm{kg}$ sodium pentobarbital) and killed by cervical dislocation. All experimental procedures were carried out in accordance with EU Directive 2010/63/EU and approved by the I Local Ethics Committee for Experiments on Animals of the Jagiellonian University in Krakow, Poland (approval numbers: 52/2014 and 102/2015).

\section{Drugs}

The studied compounds (Fig. 1): 1-[(2,6-dimethylphenoxy) ethoxyethyl]-4-(2-methoxyphenyl)piperazine hydrochloride
(HBK-14) and 1-[(2-chloro-6-methylphenoxy)ethoxyethyl]4-(2-methoxyphenyl)piperazine hydrochloride (HBK-15) were synthesized in the Department of Bioorganic Chemistry, Chair of Organic Chemistry, Pharmaceutical Faculty, Jagiellonian University (Waszkielewicz et al. 2015). HBK-14, HBK-15, and scopolamine (Sigma, Germany) were dissolved in saline, and administered intraperitoneally (i.p.) at a volume of $10 \mathrm{ml} / \mathrm{kg}$. Carbachol (Sigma, Germany) was dissolved in distilled water and used in functional experiments.

\section{Experimental protocol for chronic experiments}

After habituation period, mice were injected (i.p.) with HBK$14(1.25$ or $2.5 \mathrm{mg} / \mathrm{kg})$, HBK-15 ( $0.3,0.625$ or $1.25 \mathrm{mg} / \mathrm{kg})$, fluoxetine $(10 \mathrm{mg} / \mathrm{kg}$ - positive control) or saline (control groups) for 21 consecutive days (Fig. 2). After that time the animals were subjected to behavioral tests (i.e. forced swim test and spontaneous locomotor activity), which were then followed by tissue collection and biochemical analysis. The doses of compounds used in this study were based on our previous experiments (Pytka et al. 2015b; Pytka et al. 2015a).

\section{Forced swim test}

Forced swim test was performed according to the method previously described (Borsini 1995; Pytka et al. 2015c) with some modifications (Tanaka and Telegdy 2008; Pytka et al. 2015c; Pytka et al. 2016a). Mice were placed individually in glass cylinders (height $25 \mathrm{~cm}$, diameter $10 \mathrm{~cm}$ ) containing $10 \mathrm{~cm}^{3}$ of water $\left(23-25^{\circ} \mathrm{C}\right)$, and left there for $6 \mathrm{~min}$. The total time of immobility, swimming and climbing was recorded during the final $4 \mathrm{~min}$ of the test. The animal was regarded as: 1) immobile when it was floating passively in the water or making only small movements to keep its head above the water surface; 2) climbing when it was making vertical movements against walls; 3 ) swimming when it was making horizontal movements across the water surface. The experiments were recorded and scored using aLab.io software by a trained observer blind to the treatments.

\section{Spontaneous locomotor activity}

The locomotor activity was performed as previously described (Pytka et al. 2015b). Briefly, locomotor activity was recorded for each animal individually using activity cages, which were supplied with I.R. horizontal beam emitters (Activity Cage 7441, Ugo Basile, Italy) connected to a counter for the recording of light-beam interruptions. Each mouse was placed in a cage $(40 \mathrm{~cm} \times 40 \mathrm{~cm} \times 31 \mathrm{~cm})$, made of clear Perspex, for a 30 min habituation period. After that time the number of crossings of photobeams was measured from the 2nd to the 6th $\min$ (i.e., the time equal to the observation period in the 


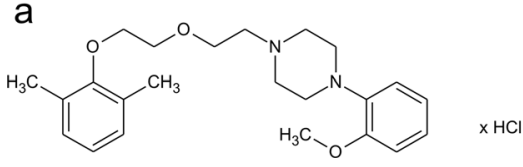

Fig. 1 Chemical structures of the studied dual $5-\mathrm{HT}_{1 \mathrm{~A}}$ and $5-\mathrm{HT}_{7}$ receptor antagonists. a 1-[(2,6-dimethylphenoxy)ethoxyethyl]-4-(2methoxyphenyl)piperazine hydrochloride (HBK-14); b 1-[(2-chloro-6-

forced swim test). The cages were disinfected with $70 \%$ ethanol after each mouse.

\section{The evaluation of serotonin level in the hippocampus}

Removed hippocampi were rinsed with phosphate-buffered saline (PBS) to remove excess blood. The tissue was homogenized in PBS buffer enriched with $1 \%$ stabilizer, included in the kit, and stored in $-80^{\circ} \mathrm{C}$. After two freeze-thaw cycles that were performed to break the cell membranes, the homogenates were centrifuged for $10 \mathrm{~min}$ at $4000 \mathrm{x} \mathrm{g}$. Removed supernate were aliquoted and stored at $-80^{\circ} \mathrm{C}$ until analysis.

Aliquots of each sample were taken and serotonin levels were determined using an ELISA kit from Labor Diagnostyka Nord GmbH \&Co. KG (LDN, Nordhorn, Germany), according to the manufacturer's instructions. The absorbance was read at $450 \mathrm{~nm}$ and the corresponding concentration was determined from the standard curve.

The serotonin level in murine hippocampi was additionally evaluated after single injection.

\section{The influence on the guinea-pig ileum contraction induced by carbachol}

The experiment was performed according to the method described by Mogilski and colleagues (2015). A segment $(15 \mathrm{~cm})$ of male guinea-pig ileum was excised from the small intestine and immersed into a Krebs solution $(\mathrm{NaCl} 120 \mathrm{mM}$, $\mathrm{KCl} 5.6 \mathrm{mM}, \mathrm{MgCl}_{2} 2.2 \mathrm{mM}, \mathrm{CaCl}_{2} 2.4 \mathrm{mM}, \mathrm{NaHCO}_{3}$ $19 \mathrm{mM}$, glucose $10 \mathrm{mM})$. The part of the ileum $(5 \mathrm{~cm})$ that was the closest to the ileo-cecal junction was removed. After $2 \mathrm{~cm}$-long fragments of the ileum were cut, each of them was placed in $20 \mathrm{ml}$ chamber of tissue organ bath system (Tissue

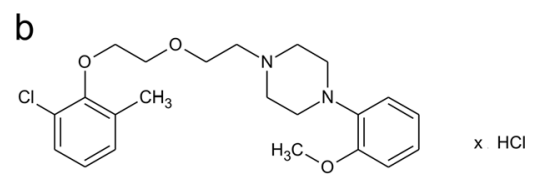

methylphenoxy)ethoxyethyl]-4-(2-methoxyphenyl)piperazine hydrochloride (HBK-15)

Organ Bath System - 750 TOBS, DMT, Denmark) filled with the Krebs solution at $37{ }^{\circ} \mathrm{C}$, pH 7.4, with constant oxygenation $\left(\mathrm{O}_{2} / \mathrm{CO}_{2}, 19: 1\right)$. The segments were stretched by means of closing clips between the metal rod and the forcedisplacement transducer. The preparations were allowed to stabilize in organ baths for 60 min under a resting tension of $0.5 \mathrm{~g}$ and were washed every $15 \mathrm{~min}$ with fresh Krebs solution. After the equilibration period a cumulative concentration-response curve was constructed for muscarinic receptor agonist: carbachol $(3 \mathrm{nM}-3 \mu \mathrm{M})$. Then the tissues were incubated with one of the concentrations of tested compounds for $15 \mathrm{~min}$ and the next cumulative concentration curve to the agonist was constructed. Only one concentration of the potential antagonist was tested in each piece of the tissue. The experiment was repeated four to eight times.

\section{Step-through passive avoidance task in mice after acute administration}

Step-through passive avoidance task was performed according to the method previously described (Lee et al. 2016; Pytka et al. 2016a). The apparatus for step-through passive avoidance task consisted of two compartments, separated by an automated sliding door (LE872, Bioseb, France). For acquisition session, mice were placed individually in an illuminated white compartment $(20 \mathrm{~cm} \times 21 \mathrm{~cm} \times 20 \mathrm{~cm}, 1000 \mathrm{~lx})$ with the closed door to a smaller dark compartment $(7.3 \mathrm{~cm} \times 7.5 \mathrm{~cm} \times 14 \mathrm{~cm}, 10 \mathrm{~lx})$ equipped with an electric grid floor (stainless steel rods through which an electric footshock is delivered). After $30 \mathrm{~s}$ the door to a smaller compartment were opened. Immediately after the mouse entered the smaller dark compartment, the door closed and the rodent was punished by an inescapable electric foot shock $(0.8 \mathrm{~mA}$

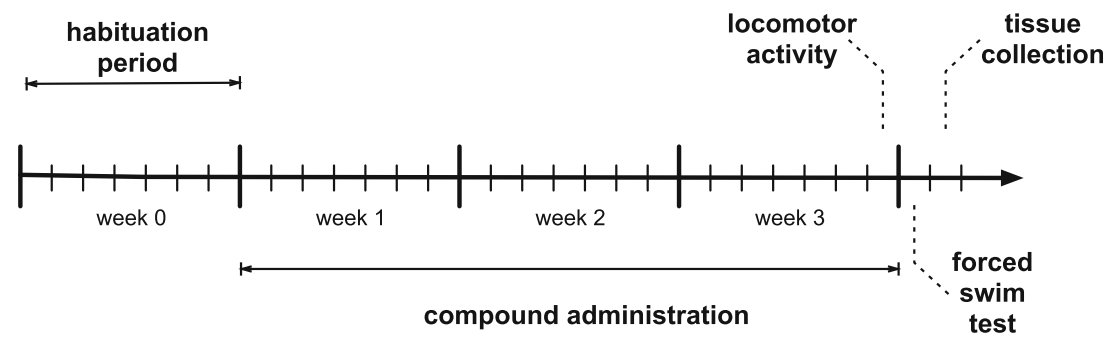

Fig. 2 A schematic diagram of chronic administration of studied compounds and behavioral testing. HBK-14 (1.25 and $2.5 \mathrm{mg} / \mathrm{kg})$, HBK-15 $(0.3,0.625$ and $1.25 \mathrm{mg} / \mathrm{kg})$, fluoxetine $(10 \mathrm{mg} / \mathrm{kg})$ or saline were administered intraperitoneally to mice for 21 consecutive days. Control groups received $0.9 \% \mathrm{NaCl}$ (saline) 
for $2 \mathrm{~s}$ ). The mice, which did not enter the dark compartment within $50 \mathrm{~s}$ were excluded from the study. On the following day ( $24 \mathrm{~h}$ later), the pretrained animals were placed again into the illuminated compartment and observed up to $300 \mathrm{~s}$ (retention session). The experimental procedure was similar to acquisition session, but this time mice did not receive the electric shock after the entrance to the smaller dark compartment. Mice, which avoided the dark compartment for $300 \mathrm{~s}$ were considered to remember the task.

\section{Evaluation of cognitive-enhancing properties in naïve mice}

HBK-14 (1.25 or $2.5 \mathrm{mg} / \mathrm{kg})$, HBK-15 $(0.3,0.625$ or $1.25 \mathrm{mg} /$ $\mathrm{kg})$ or fluoxetine $(5,10,20 \mathrm{mg} / \mathrm{kg})$ were administered (i.p.) $30 \mathrm{~min}$ before acquisition trial. Control groups were injected (i.p.) with saline. The doses of compounds used in this study were based on our previous experiments (Pytka et al. 2015b; Pytka et al. 2015a).

\section{The effect on scopolamine-induced cognitive dysfunction}

HBK-14 (1.25 or $2.5 \mathrm{mg} / \mathrm{kg})$, HBK-15 $(0.3,0.625$ or $1.25 \mathrm{mg} /$ $\mathrm{kg})$ or fluoxetine $(5,10,20 \mathrm{mg} / \mathrm{kg})$ and scopolamine $(1 \mathrm{mg} /$ $\mathrm{kg}$ ) were administered (i.p.) $30 \mathrm{~min}$ before the acquisition trial. Control groups were injected (i.p.) with saline. The doses of the studied compounds and scopolamine were based on our previous experiments (Pytka et al. 2015b; Pytka et al. 2015a; Pytka et al. 2016a).

\section{Data analysis}

Results are presented as means \pm S.E.M. In the forced swim test, spontaneous locomotor activity, and biochemical studies comparisons between experimental and control groups were performed by one-way ANOVA, followed by Newman-Keuls post hoc, when three or more groups were compared or Student's t-test if two groups were compared. In the stepthrough passive avoidance task one-way ANOVA followed by Turkey's test post hoc was used. A value of $p<0.05$ was considered to be significant.

In functional experiments $\mathrm{pK}_{\mathrm{B}}$ value was estimated using the following equation (Arunlakshana and Schild 1959):

$p K_{B}=-\log _{10} \frac{B}{D R-1}$

Where $\mathrm{B}$ was the molar antagonist concentration and DR was the ratio between the $\mathrm{EC}_{50}$ of the agonist in the presence and absence of the antagonist. $\mathrm{pK}_{\mathrm{B}}$ value was equivalent to the $\mathrm{pA}_{2}$ value and was calculated if only one concentration of tested compound was effective.

\section{Results}

Antidepressant-like activity of studied compounds and fluoxetine in the forced swim test in mice after chronic treatment

HBK-14 $(2.5 \mathrm{mg} / \mathrm{kg})$ injected for 21 days significantly reduced immobility of mice by $21 \%[\mathrm{~F}(2,21)=5.683$, $p<0.05]$, increased swimming behavior by $67 \%$ $[\mathrm{F}(2,21)=4.270, p<0.05]$ and had no effect on climbing $[\mathrm{F}(2,21)=3.364, \mathrm{~ns}]$ (Fig. 3a).

Chronic treatment with HBK-15 (0.625 and $1.25 \mathrm{mg} / \mathrm{kg})$ significantly decreased immobility of mice by $19 \%$ and $29 \%$ $[\mathrm{F}(3,28)=6.929, p<0.01]$, respectively (Fig. 3b). The compound administered for 21 days caused an increase in swimming behavior by $75 \%$ at the dose $0.625 \mathrm{mg} / \mathrm{kg}$ and by $111 \%$ at the dose $1.25 \mathrm{mg} / \mathrm{kg}[\mathrm{F}(3,28)=6.558, p<0.01]$. HBK-15 had no significant influence on climbing $[\mathrm{F}(3,28)=0.356, \mathrm{~ns}]$.

Fluoxetine $(10 \mathrm{mg} / \mathrm{kg})$ administered for 21 consecutive days significantly decreased immobility by $27 \%$ $[\mathrm{t}(14)=3.864, p<0.01]$, increased swimming by $133 \%$ $[\mathrm{t}(14)=4.604 \mathrm{~ns}]$, and had no influence on climbing behavior $[\mathrm{t}(14)=0.483, \mathrm{~ns}]$ (Fig. 3c).

\section{The influence of studied compounds or fluoxetine on locomotor activity of mice after chronic treatment}

Neither HBK-14 $(1.25$ and $2.5 \mathrm{mg} / \mathrm{kg})[\mathrm{F}(2,21)=0.038, \mathrm{~ns}]$, HBK-15 $(0.3,0.625$ and $1.25 \mathrm{mg} / \mathrm{kg})[\mathrm{F}(3,28)=0.588, \mathrm{~ns}]$ nor fluoxetine $(10 \mathrm{mg} / \mathrm{kg})[\mathrm{t}(14)=0.436, \mathrm{~ns}]$ influenced locomotor activity in mice (Table 1 ).

The influence of studied compounds on serotonin levels in murine hippocampi after acute and chronic treatment

Acute treatment with the studied compounds showed no effect on the hippocampal serotonin levels (Fig. 4a). Administration of HBK-14 (2.5 mg/kg) and HBK-15 (0.625 and $1.25 \mathrm{mg} / \mathrm{kg})$ for 21 days significantly increased serotonin levels in murine hippocampi by $25 \%, 46 \%$ and $48 \%$, respectively (Fig. 4b).

\section{The influence on the guinea-pig ileum contraction induced by carbachol}

Carbachol induced concentration-dependent guinea-pig ileum contractions; the $\mathrm{pEC}_{50}$ value (negative logarithm of the agonist concentration at which the response reached $50 \%$ of the maximal response) was $7.09 \pm 0.05$ (Fig. 5). Neither HBK-14 nor HBK-15 administered alone induced ileal contractions (data not shown). HBK-14 (1 and $3 \mu \mathrm{M})$ did not inhibit carbachol-induced contractions (Fig. 5a); however, at the concentration $10 \mu \mathrm{M}$ it decreased the maximum effect of carbachol by $25 \%$, which suggested a non-competitive antagonism. 
Fig. 3 Antidepressant-like effect of HBK-14, HBK-15 and fluoxetine after chronic treatment in mice. HBK-14, HBK-15, fluoxetine or saline were administered intraperitoneally to mice for 21 consecutive days. $24 \mathrm{~h}$ after the last injection the forced swim test was performed. Control groups received $0.9 \% \mathrm{NaCl}$ (saline). Statistical analysis: one-way ANOVA (Newman-Keuls post hoc) when three or more groups were compared or Student t-test if two groups were compared, $* p<0.05, * * p<0.01$, $* * * p<0.001$ vs respective salinetreated group; $n=8$ mice per group a

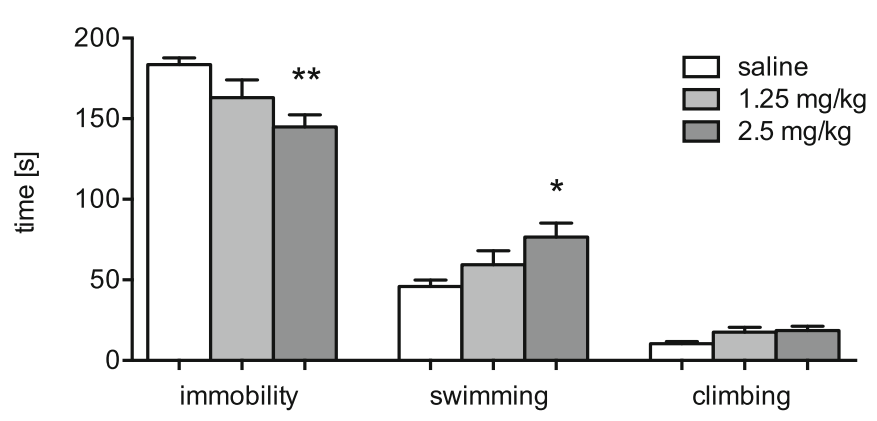

b

HBK-15

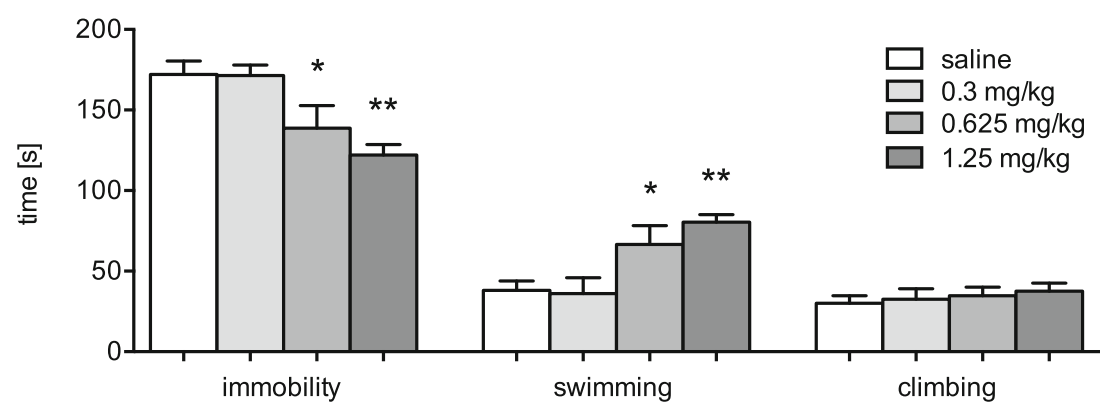

C

Fluoxetine

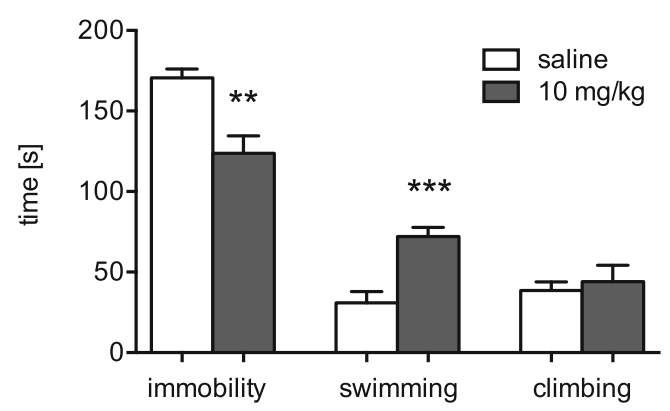

HBK-15 $(1 \mu \mathrm{M})$ slightly shifted the carbachol response to the right without decreasing the maximal response, which indicated a competitive interaction with muscarinic receptors. The affinity expressed as the $\mathrm{pK}_{\mathrm{B}}$ was $6.01 \pm 0.01$. Higher concentrations of HBK-15 (3 and $10 \mu \mathrm{M})$ decreased the maximum effect of carbachol by $21 \%$ and $65 \%$, respectively (Fig. $5 \mathrm{~b}$ ). This suggested a non-competitive type of antagonism.

\section{The effect of studied compounds on learning and memory in the step-through passive avoidance task in mice}

\section{Evaluation of cognitive-enhancing properties in naïve mice}

In the acquisition trial of the passive avoidance task, none of the compounds affected latency times [HBK-14:
$\mathrm{F}(2,27)=0.393$, ns; HBK-15: $\mathrm{F}(3,31)=0.377$, ns; fluoxetine: $F(3,36)=0.282$, ns] (Fig. 6a). However, in retention trial HBK-15 $(0.625 \mathrm{mg} / \mathrm{kg})$ significantly increased latency time $[\mathrm{F}(3,31)=3.564, p<0.05]$ (Fig. 5a). In contrast, neither HBK-14 (1.25 and $2.5 \mathrm{mg} / \mathrm{kg})$ nor fluoxetine $(5,10$ and $20 \mathrm{mg} / \mathrm{kg})$ influenced latencies in retention trial $[\mathrm{F}(2,27)=0.305$, ns and $\mathrm{F}(3,36)=0.0 .96$, ns, respectively] (Fig. 6a).

\section{The effect on scopolamine-induced cognitive dysfunction}

In the acquisition trial, neither the studied compounds $[\mathrm{HBK}-14: \mathrm{F}(3,36)=2.446, \mathrm{~ns}, \mathrm{HBK}-15$ : $\mathrm{F}(4,45)=2.030, \mathrm{~ns}]$ nor fluoxetine $[\mathrm{F}(4,45)=2.197, \mathrm{~ns}]$ affected latency times; however we observed significant 
Table 1 HBK-14, HBK-15 and fluoxetine did not influence locomotor activity of mice

\begin{tabular}{lll}
\hline Treatment & Dose $(\mathrm{mg} / \mathrm{kg})$ & Number of crossings \pm S.E. M \\
\hline Saline & - & $397.6 \pm 72.9$ \\
HBK-14 & 1.25 & $394.4 \pm 45.2$ \\
& 2.5 & $415.5 \pm 53.6$ \\
Saline & - & $424.5 \pm 61.5$ \\
HBK-15 & 0.3 & $363.3 \pm 65.4$ \\
& 0.625 & $472.0 \pm 47.8$ \\
& 1.25 & $442.0 \pm 63.7$ \\
Saline & - & $430.6 \pm 34.9$ \\
Fluoxetine & 10 & $405.5 \pm 45.9$ \\
\hline
\end{tabular}

HBK-14, HBK-15, fluoxetine or saline were administered intraperitoneally to mice for 21 consecutive days. The locomotor activity was recorded individually for each animal in activity cages between the 2 nd and the 6th $\min$ (i.e., the time equal to the observation period in the forced swim test). Control groups received $0.9 \% \mathrm{NaCl}$ (saline) Statistical analysis: one-way ANOVA (Newman-Keuls post hoc) when three or more groups were compared or Student's t-test if two groups were compared; $n=8$ mice per group

differences in the retention trial (Fig. 6b). Scopolamine $(1 \mathrm{mg} / \mathrm{kg}$ ) compared with control (saline) significantly reduced latency times, and this effect was reversed by HBK-15 $(0.625 \mathrm{mg} / \mathrm{kg})[\mathrm{F}(4,45)=29.22, p<0.0001]$ but not HBK-14 (1.25 and 2.25) $[\mathrm{F}(3,36)=53.71$, $p<0.0001]$ or fluoxetine $(5,10$ and $20 \mathrm{mg} / \mathrm{kg}$ ) $[\mathrm{F}(4,45)=58.86, p<0.0001]$ (Fig. 6b).

\section{Discussion}

In the present study we found that dual $5-\mathrm{HT}_{1 \mathrm{~A}}$ and $5-\mathrm{HT}_{7}$ antagonists i.e. HBK-14 and HBK-15 possessed antidepressant-like activity and increased serotonin levels in the hippocampus after chronic treatment. HBK-15 possessed very weak cholinolytic properties, whereas HBK-14 did not block muscarinic receptors. Moreover, acute administration of HBK-15 enhanced memory of mice and significantly ameliorated memory impairment caused by scopolamine.

Although the data are inconsistent some studies show that $5-\mathrm{HT}_{1 \mathrm{~A}}$ and $5-\mathrm{HT}_{7}$ receptor blockade might have potential in the treatment of major depressive disorder (reviewed in Pytka et al. 2016c). Researchers proved that 5- $\mathrm{HT}_{1 \mathrm{~A}}$ receptor deficient mice were less immobile in the forced swim test than wild-type control (Parks et al. 1998; Heisler et al. 1998). This suggests that the lack of functional $5-\mathrm{HT}_{1 \mathrm{~A}}$ receptors favors a less depressed phenotype. Similarly, deletion of $5-\mathrm{HT}_{7}$ gene (Guscott et al. 2005) as well as 5- $\mathrm{HT}_{7}$ receptor antagonists (Wesołowska et al. 2006) resulted in antidepressant-like effect in various animal tests. Altogether, these findings indicate that $5-\mathrm{HT}_{1 \mathrm{~A}}$ and $5-\mathrm{HT}_{7}$ receptor antagonists may have potential as antidepressants.

Our previous studies revealed that dual $5-\mathrm{HT}_{1 \mathrm{~A}}$ and $5-\mathrm{HT}_{7}$ receptor antagonists i.e. HBK-14 and HBK-15 possessed significant antidepressant-like properties after acute treatment (Waszkielewicz et al. 2015; Pytka et al. 2015a). Both compounds showed $\alpha_{1}$-adrenolytic properties, and only HBK-15 did not lower blood pressure at antidepressant-like doses after
Fig. 4 The influence on serotonin levels in murine hippocampi after acute (Panel a) or chronic (Panel b) treatment with HBK-14 or HBK-15. HBK14 , HBK-15 or saline were administered intraperitoneally to mice 30 min (Panel a) or for 21 consecutive days (Panel b) before tissue collection. Control groups received $0.9 \% \mathrm{NaCl}$ (saline). Statistical analysis: one-way ANOVA (Newman-Keuls post hoc), ${ }^{*} p<0.05, * * p<0.01 \mathrm{vs}$ respective saline-treated group; $n=6$ mice per group a

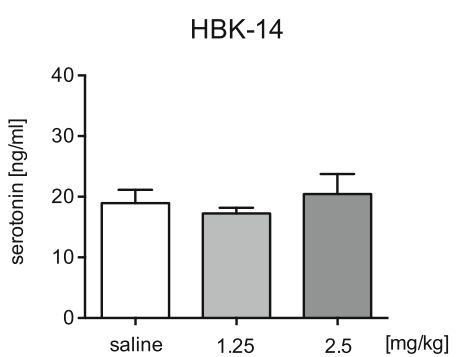

b

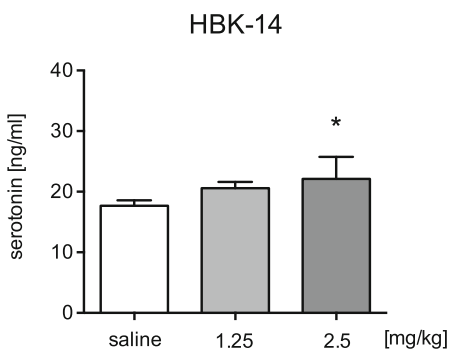

acute

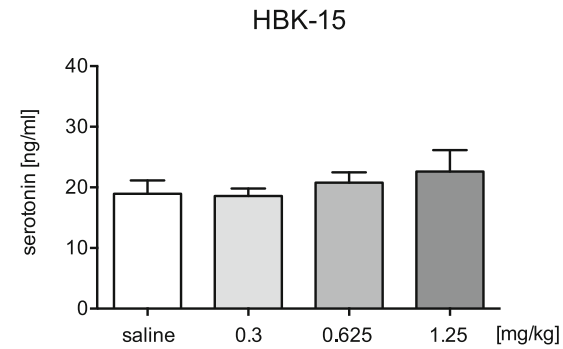

chronic

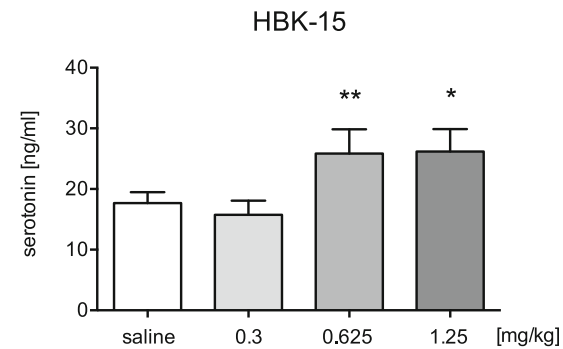


a

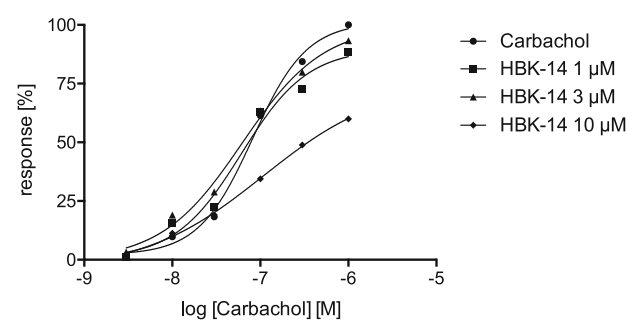

Fig. 5 The effect of HBK-14 and HBK-15 on muscarinic receptor in isolated guinea-pig ileum. Concentration-response curves to carbachol in the absence or presence of increasing concentrations of HBK-14 or

single administration (Pytka et al. 2016b). Interestingly, none of the compounds affected blood pressure after chronic administration (Pytka et al. 2016d). Here, we evaluated antidepressantlike activity of HBK-14 and HBK-15 after chronic administration in mice. Both compounds injected for 21 days showed antidepressant-like activities in the mouse forced swim test. None of them affected locomotor activity of mice; therefore, the observed effects were specific. Both compounds increased swimming, whereas had no influence on climbing behaviors. Since serotonin-targeting antidepressants increase swimming behavior in rodents (Nakatomi et al. 2008), we concluded that the serotonergic system was involved in the antidepressant-like effect of the studied compounds. HBK-15 showed stronger antidepressant-like properties than HBK-14, which is in agreement with our previous findings (Pytka et al. 2015a). Interestingly, HBK-15 administered chronically showed antidepressant-like properties at lower dose $(0.625 \mathrm{mg} / \mathrm{kg})$ than the dose active after acute treatment $(1.25 \mathrm{mg} / \mathrm{kg})$ (Pytka et al. b

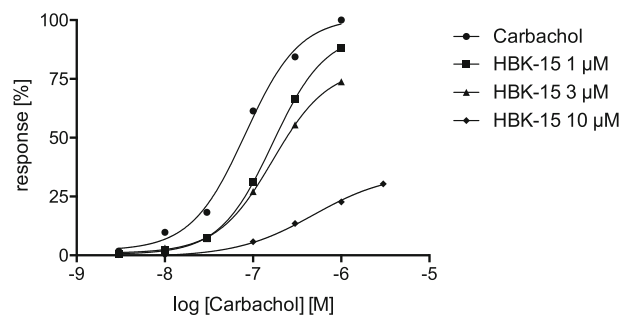

HBK-15. The results are expressed as the percentage of maximal response to carbachol in the corresponding concentration-response curve. Each point represents the mean \pm S.E. $\mathrm{M}(n=4-8)$

2015a). This is a common phenomenon for antidepressants, since antidepressant effect requires adaptive changes at the neuronal receptor level. Similarly, fluoxetine (Contreras et al. 2001) or Hypericum perforatum (Lozanondash and Rodriguez-L 2010) administered chronically showed antidepressant-like effects at lower doses than those active after acute injection.

According to the serotonin hypothesis a deficit in brain serotonergic activity might be a cause of depression or an important vulnerability factor in this disease. The findings are divergent, but some studies reported a decrease in serotonin or its metabolite levels in the brains of suicide victims or suicide attempters (for review, see Mann et al. 1989). The reduced levels of serotonin were most frequently found in brainstem. Although there are many other theories, the serotonin hypothesis is still to date, as most antidepressants in clinical use enhance the serotonergic neurotransmission.

Since many antidepressants elevate serotonin levels, we investigated the influence of studied compounds on the level

a
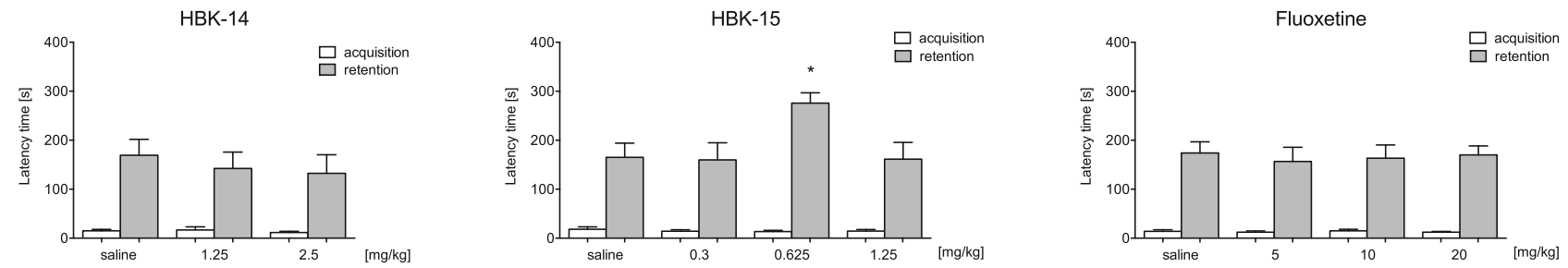

$b$
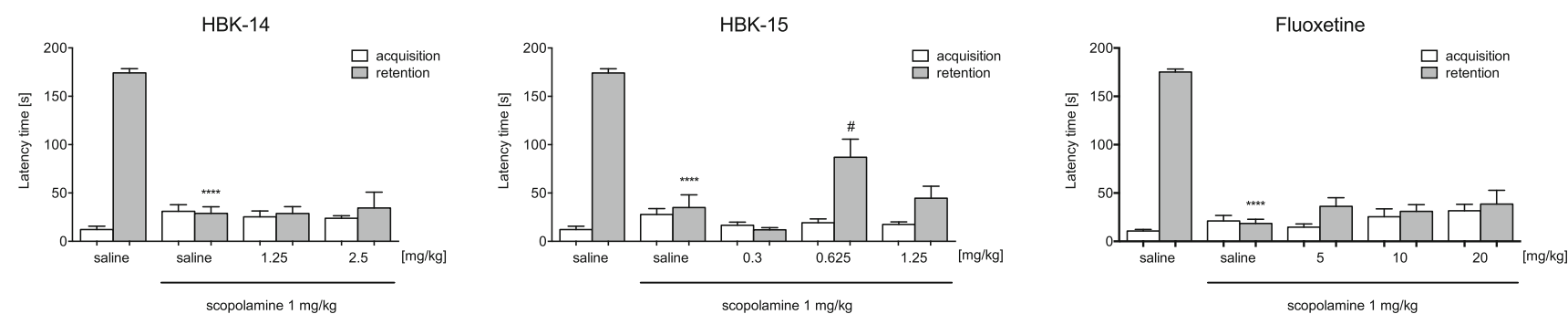

Fig. 6 The effect of studied compounds or fluoxetine on learning and memory in the mouse step-through passive avoidance task. HBK-14, HBK-15, fluoxetine or saline and/or scopolamine were administered intraperitoneally to mice $30 \mathrm{~min}$ before the acquisition trial of the stepthrough passive avoidance test. The compounds were injected alone

(Panel a) or jointly with scopolamine (Panel b). Control groups received $0.9 \% \mathrm{NaCl}$ (saline). Statistical analysis: one-way ANOVA (Turkey post hoc), $* p<0.05, * * * * p<0.0001$ vs respective saline-treated group, $\# p<0.05$ vs respective saline + scopolamine-treated group $n=8-10$ mice per group 
of serotonin in the hippocampus after acute and chronic treatment. Scientists proved that hippocampus plays a central role in major depression (for review see: Campbell and Macqueen 2004). Our experiments showed that chronic (but not acute) treatment with the studied compounds caused a significant increase in the level of hippocampal serotonin. In both cases the increase in serotonin levels was in parallel with a decrease in the immobility of mice in the forced swim test. Since hippocampus plays crucial role in mood disorders and reduced serotonin levels might occur in depression, we believe that the fact that the studied compounds elevate hippocampal serotonin levels might be beneficial in depressed individuals.

Cognitive dysfunction is very common among patients with major depressive disorder and significantly affects their capacity to function (Darcet et al. 2016). Carvalho et al. (2015) suggested that several factors might contribute to cognitive dysfunction in major depressive disorder i.e. hyperactive hypothalamic-pituitary-adrenal axis, an increase in oxidative and nitrosative stress, increased apoptosis or diminished neurotrophic support. The cognitive impairments mostly occur during depressive episodes and include deficits in executive functions (attention, processing speed, cognitive flexibility) or learning and memory.

Bearing that in mind, in the second part of our studies, we examined the influence of dual $5-\mathrm{HT}_{1 \mathrm{~A}}$ and $5-\mathrm{HT}_{7}$ antagonists on learning and memory in mice after acute administration. Since the blockade of muscarinic receptors may cause various unfavorable effects such as memory impairment, we first investigated potential cholinolityc properties of the studied compounds. Our experiments revealed that HBK-14 possessed no, and HBK-15 very weak and negligible cholinolytic activity. Both compounds reduced carbachol maxima at the concentration of $10 \mu \mathrm{M}$, which suggested a non-specific or additional site of interaction (most likely not related to muscarinic receptors). In comparison, previous experiments performed in our laboratory showed that $\mathrm{pA}_{2}$ value for atropine (cholinolytic drug) was 8.985 (Mogilski et al. 2015), which was a much higher value than $\mathrm{pK}_{\mathrm{B}}$ (5.99) obtained for HBK-15.

The data on the effects of $5-\mathrm{HT}_{1 \mathrm{~A}}$ and $5-\mathrm{HT}_{7}$ receptor ligands on learning and memory in rodents are ambiguous. Galeotti et al. (2000) as well as Tsuji et al. (2002) proved that stimulating $5-\mathrm{HT}_{1 \mathrm{~A}}$ receptor in mice promoted learning and memory. Opposite results presented Madjid et al. (2006), who reported that $5-\mathrm{HT}_{1 \mathrm{~A}}$ antagonists facilitated aversive learning in mice. Interestingly, the Authors also showed that 8-OHDPAT (5-HT $1 \mathrm{~A}$ agonist) displayed biphasic effect on retention times. Similarly, studies on the role of $5-\mathrm{HT}_{7}$ receptor in cognitive function are also conflicting (reviewed in Meneses 2014). Nevertheless, $5-\mathrm{HT}_{7}{ }^{-1-}$ mice showed impaired contextual hippocampal-dependent learning and decreased longterm synaptic plasticity in the hippocampus (Roberts et al. 2004). Moreover, both genetic and pharmacological inactivation of $5-\mathrm{HT}_{7}$ receptor in mice resulted in deficits in hippocampus-associated spatial memory in the location recognition test (Sarkisyan and Hedlund 2009).

In the present study, we determined the influence of both dual $5 \mathrm{HT}_{1 \mathrm{~A}}$ and $5-\mathrm{HT}_{7}$ antagonists on learning and memory using the step-through passive avoidance test, which is a hippocampus-dependent memory task. In this test animals need to inhibit their natural tendency to enter the dark chamber. We showed that only HBK-15 administered alone possessed memory-enhancing properties in passive avoidance task. Moreover, the compound ameliorated memory deficits induced by scopolamine in this test. HBK-14 and fluoxetine were inactive in the step-through passive avoidance task. Interestingly, in both experiments HBK-15 displayed an inverted U-shaped dose-effect curve $(0.625 \mathrm{mg} / \mathrm{kg})$. This nonlinear relationship was frequently reported in pharmacological studies on cognitive functions and memory (Baldi and Bucherelli 2005). Although an inverted U-shaped dose-effect is widely described, it is very poorly understood. Scientists proposed several theories (e.g. arousal hypothesis), but the effect is most likely multifactorial and therefore difficult to explain.

Studies suggested that $5-\mathrm{HT}_{7}$ receptor blockade resulted in the cognitive deficits in mice (Sarkisyan and Hedlund 2009; Freret et al. 2014). Eriksson et al. (2008) showed that even though SB-269970 (administered alone before the training session) had no effect on retention latency, it enhanced amnestic effects of 8-OH-DPAT in the passive avoidance test in mice. Since 8-OH-DPAT is also $5-\mathrm{HT}_{7}$ receptor agonist, the Authors concluded that $5-\mathrm{HT}_{7}$ receptor stimulation by $8-\mathrm{OH}-$ DPAT counteracts $5-\mathrm{HT}_{1 \mathrm{~A}}$ receptor-mediated impairments in hippocampal-dependent contextual learning. Our findings are in agreement with the above studies, since our previous experiments revealed that HBK-15 compared with HBK-14 showed around three-fold stronger antagonistic properties at $5-\mathrm{HT}_{1 \mathrm{~A}}$ and weaker at 5- $\mathrm{HT}_{7}$ receptor (Pytka et al. 2015a). We believe that these slight differences in HBK-14 and HBK-15 receptor profiles might be responsible for the observed differences in the activity in passive avoidance task.

The limitation of our study was the fact that antidepressantlike activity of the compounds was not tested using animal model of depression (e.g. chronic unpredictable mild stress). Since depression is closely associated with stress, this would provide more insight into the therapeutic potential of studied compounds. Furthermore, we should also confirm memoryenhancing activity of HBK-15 using other tests, such as Morris water maze or Y-maze, as well as after chronic treatment.

Therefore, in future studies we plan to examine antidepressant-like properties of both compounds utilizing animal models of depression. We also intend to evaluate the influence of acute and repeated administration of HBK-15 on learning and memory using other behavioral paradigms in rodents. 


\section{Conclusion}

We demonstrated that both dual 5- $\mathrm{HT}_{1 \mathrm{~A}}$ and $5-\mathrm{HT}_{7}$ receptor antagonists (i.e. HBK-14 and HBK-15) possessed antidepressant-like activity and increased serotonin levels in the hippocampus after chronic treatment. None of the compounds displayed strong cholinolytic properties. Moreover, HBK-15 showed memory-enhancing activity and ameliorated memory impairment caused by scopolamine after acute administration. We think that dual $5-\mathrm{HT}_{1 \mathrm{~A}}$ and $5-\mathrm{HT}_{7}$ antagonists might have potential in the treatment of depressive disorders with cognitive dysfunction, and therefore require extended studies to explore their pharmacological profile.

Acknowledgments We wish to thank Agnieszka Niedbał and Teresa Dobrut for their technical assistance. This study was supported by Jagiellonian University grant number K/DSC/001955.

\section{Compliance with ethical standards}

Ethical approval All applicable international, national, and/or institutional guidelines for the care and use of animals were followed. All procedures performed in studies involving animals were in accordance with the ethical standards of the institution or practice at which the studies were conducted.

Open Access This article is distributed under the terms of the Creative Commons Attribution 4.0 International License (http:// creativecommons.org/licenses/by/4.0/), which permits unrestricted use, distribution, and reproduction in any medium, provided you give appropriate credit to the original author(s) and the source, provide a link to the Creative Commons license, and indicate if changes were made.

\section{References}

Arunlakshana O, Schild HO (1959) Some quantitative uses of drug antagonists. Br J Pharmacol Chemother 14:48-58. doi:10.1111/j.14765381.1959.tb00928.x

Baldi E, Bucherelli C (2005) The inverted "u-shaped" dose-effect relationships in learning and memory: modulation of arousal and consolidation. Nonlinearity Biol Toxicol Med 3:9-21. doi:10.2201 /nonlin.003.01.002

Biringer E, Rongve A, Lund A (2009) A review of modern antidepressants effects on neurocognitive function. CPSR 5:164-174. doi:10.2174/157340009788971137

Borsini F (1995) Role of the serotonergic system in the forced swimming test. Neurosci Biobehav Rev 19:377-395

Campbell S, Macqueen G (2004) The role of the hippocampus in the pathophysiology of major depression. J Psychiatry Neurosci 29: 417-426

Carvalho A, Miskowiak K, Hyphantis T et al (2015) Cognitive dysfunction in depression - pathophysiology and novel targets. CNS Neurol Disord Drug Targets 13:1819-1835. doi:10.2174 /1871527313666141130203627

Contreras CM, Rodriguez-Landa JF, Gutiérrez-García AG, BernalMorales B (2001) The lowest effective dose of fluoxetine in the forced swim test significantly affects the firing rate of lateral septal nucleus neurones in the rat. J Psychopharmacol 15:231-236
Darcet F, Gardier AM, Gaillard R et al (2016) Cognitive dysfunction in major depressive disorder. A Translational Review in Animal Models of the Disease. Pharmaceuticals. doi:10.3390/ph9010009

Eriksson TM, Golkar A, Ekström JC et al (2008) 5-HT7 receptor stimulation by $8-\mathrm{OH}-\mathrm{DPAT}$ counteracts the impairing effect of 5-HT1A receptor stimulation on contextual learning in mice. Eur J Pharmacol 596:107-110. doi:10.1016/j.ejphar.2008.08.026

Freret T, Paizanis E, Beaudet G et al (2014) Modulation of 5-HT7 receptor: effect on object recognition performances in mice. Psychopharmacology 231:393-400. doi:10.1007/s00213-0133247-x

Galeotti N, Ghelardini C, Bartolini A (2000) Role of 5-HT1A receptors in a mouse passive avoidance paradigm. Jpn J Pharmacol 84:418-424

Glikmann-Johnston Y, Saling MM, Reutens DC, Stout JC (2015) Hippocampal 5-HT1A receptor and spatial learning and memory. Front Pharmacol 6:289. doi:10.3389/fphar.2015.00289

Guscott M, Bristow LJ, Hadingham K et al (2005) Genetic knockout and pharmacological blockade studies of the 5-HT7 receptor suggest therapeutic potential in depression. Neuropharmacology 48:492502. doi:10.1016/j.neuropharm.2004.11.015

Heisler LK, Chu HM, Brennan TJ et al (1998) Elevated anxiety and antidepressant-like responses in serotonin 5-HT1A receptor mutant mice. Proc Natl Acad Sci U S A 95:15049-15054

Lee HE, Jeon SJ, Ryu B et al (2016) Swertisin, a C-glucosylflavone, ameliorates scopolamine-induced memory impairment in mice with its adenosine A1 receptor antagonistic property. Behav Brain Res 306:137-145. doi:10.1016/j.bbr.2016.03.030

Lozanondash R, Rodriguez-L JF (2010) Antidepressant-like effects of two commercially available products of Hypericum perforatum in the forced swim test: a long-term study. J Med Plant Res 4:131-137

Madjid N, Tottie EE, Lüttgen M et al (2006) 5-Hydroxytryptamine 1A receptor blockade facilitates aversive learning in mice: interactions with cholinergic and glutamatergic mechanisms. J Pharmacol Exp Ther 316:581-591. doi:10.1124/jpet.105.092262

Mann JJ, Arango V, Marzuk PM et al (1989) Evidence for the 5-HT hypothesis of suicide. A review of post-mortem studies. Br J Psychiatry Suppl 8:7-14

McIntyre RS, Harrison J, Loft $\mathrm{H}$ et al (2016) The effects of vortioxetine on cognitive function in patients with major depressive disorder (MDD): a meta-analysis of three randomized controlled trials. Int J Neuropsychopharm . doi:10.1093/ijnp/pyw055pyw055

Meneses A (2014) Memory formation and memory alterations: 5-HT6 and 5-HT7 receptors, novel alternative. Rev Neurosci 25:325-356. doi:10.1515/revneuro-2014-0001

Mogilski S, Kubacka M, Redzicka A et al (2015) Antinociceptive, antiinflammatory and smooth muscle relaxant activities of the pyrrolo[3,4-d]pyridazinone derivatives: possible mechanisms of action. Pharmacol Biochem Behav 133:99-110. doi:10.1016/j. pbb.2015.03.019

Nakatomi Y, Yokoyama C, Kinoshita S et al (2008) Serotonergic mediation of the antidepressant-like effect of the green leaves odor in mice. Neurosci Lett 436:167-170. doi:10.1016/j.neulet.2008.03.013

Parks CL, Robinson PS, Sibille E et al (1998) Increased anxiety of mice lacking the serotonin1A receptor. Proc Natl Acad Sci U S A 95: 10734-10739

Pytka K, Partyka A, Jastrzębska-Więsek M et al (2015a) Antidepressantand anxiolytic-like effects of new dual 5-HT1A and 5-HT7 antagonists in animal models. PLoS One 10:e142499. doi:10.1371 journal.pone.0142499

Pytka K, Rapacz A, Zygmunt M et al (2015b) Antidepressant-like activity of a new piperazine derivative of xanthone in the forced swim test in mice: the involvement of serotonergic system. Pharmacol Rep 67: 160-165. doi:10.1016/j.pharep.2014.08.016

Pytka K, Walczak M, Kij A et al (2015c) The antidepressant-like activity of 6-methoxy-2-[4-(2-methoxyphenyl)piperazin-1-yl]-9H-xanthen9-one involves serotonergic 5-HT1A and 5-HT2A/C receptors 
activation. Eur J Pharmacol 764:537-546. doi:10.1016/j. ejphar.2015.07.041

Pytka K, Kazek G, Siwek A et al (2016a) HBK-7 — a new xanthone derivative and a 5-HT1A receptor antagonist with antidepressantlike properties. Pharmacol Biochem Behav 146-147:35-43. doi:10.1016/j.pbb.2016.04.005

Pytka K, Lustyk K, Żmudzka E et al (2016b) Chemically homogenous compounds with antagonistic properties at all $\alpha 1$ adrenoceptor subtypes but not $\beta 1$-adrenoceptor attenuate adrenaline-induced arrhythmia in rats. Front Pharmacol 7:48. doi:10.3389/fphar.2016.00229

Pytka K, Podkowa K, Rapacz A et al (2016c) The role of serotonergic, adrenergic and dopaminergic receptors in antidepressantlike effect. Pharmacol Rep 68:263-274. doi:10.1016/j. pharep.2015.08.007

Pytka K, Głuch-Lutwin M, Knutelska J et al (2016d) HBK-14 and HBK15 do not influence blood pressure, lipid profile, glucose level, or liver enzymes activity after chronic treatment in rats. PLoS ONE 11: e0165495. doi:10.1371/journal.pone.0165495

Roberts AJ, Krucker T, Levy CL et al (2004) Mice lacking 5-HT receptors show specific impairments in contextual learning. Eur J Neurosci 19:1913-1922. doi:10.1111/j.1460-9568.2004.03288.x
Sarkisyan G, Hedlund PB (2009) The 5-HT7 receptor is involved in allocentric spatial memory information processing. Behav Brain Res 202:26-31. doi:10.1016/j.bbr.2009.03.011

Stiedl O, Pappa E, Konradsson-Geuken Å, Ögren SO (2015) The role of the serotonin receptor subtypes 5-HT1A and 5-HT7 and its interaction in emotional learning and memory. Front Pharmacol 6:259217. doi: 10.3389/fphar.2015.00162

Tanaka M, Telegdy G (2008) Involvement of adrenergic and serotonergic receptors in antidepressant-like effect of urocortin 3 in a modified forced swimming test in mice. Brain Res Bull 77:301-305. doi:10.1016/j.brainresbull.2008.08.012

Tsuji M, Takeda H, Matsumiya T (2002) Modulation of passive avoidance in mice by the 5-HT1A receptor agonist Flesinoxan: comparison with the benzodiazepine receptor agonist diazepam. Neuropsychopharmacology 28:664-674. doi:10.1038/sj. npp. 1300080

Waszkielewicz AM, Pytka K, Rapacz A et al (2015) Synthesis and evaluation of antidepressant-like activity of some 4-substituted 1-(2methoxyphenyl)piperazine derivatives. Chem Biol Drug Des 85: 326-335. doi:10.1111/cbdd.12394

Wesołowska A, Nikiforuk A, Stachowicz K, Tatarczyńska E (2006) Effect of the selective 5-HT7 receptor antagonist SB 269970 in animal models of anxiety and depression. Neuropharmacology 51: 578-586. doi:10.1016/j.neuropharm.2006.04.017 